\title{
Genetic diversity and structure of natural Dactylis glomerata L. populations revealed by morphological and microsatellite-based (SSR/ISSR) markers
}

P. Madesis ${ }^{1 *}$, E.M. Abraham ${ }^{2 *}$, A. Kalivas ${ }^{1,3}$, I. Ganopoulos ${ }^{1,4}$ and

\section{A. Tsaftaris ${ }^{1,4}$}

${ }^{1}$ Institute of Applied Biosciences, Centre for Research and Technology Hellas, Thessaloniki, Greece

${ }^{2}$ Laboratory of Range Science, Department of Forestry and Natural Environment, Aristotle University of Thessaloniki, Thessaloniki, Greece ${ }^{3}$ Cotton and Industrial Plant Institute, Cotton Institute and Industrial Crops ELGO-DEMETER, Thermi, Greece ${ }^{4}$ Department of Genetics and Plant Breeding, School of Agriculture, Aristotle University of Thessaloniki, Thessaloniki, Greece

*These authors contributed equally to this study.

Corresponding author: E.M. Abraham

E-mail: eabraham@for.auth.gr

Genet. Mol. Res. 13 (2): 4226-4240 (2014)

Received April 25, 2013

Accepted October 1, 2013

Published June 9, 2014

DOI http://dx.doi.org/10.4238/2014.June.9.8

ABSTRACT. Dactylis glomerata L. is an important forage species in the Mediterranean region, and in other regions with a similar climate. Genetic material from 3 locations in north, central, and south Greece was studied, using morphological traits, SSR, and ISSR molecular markers. Morphological analysis revealed differences among the geographic locations studied for all morphological traits, except the number of reproductive tillers. Moreover, the highest phenotypic variation was observed on the accessions from south, while the lowest was observed on the accessions from the north. Although the results of the molecular marker analysis are indicative, a high level of 
genetic diversity at the species level was revealed by ISSRs $\left(G_{\mathrm{ST}}=0.291\right)$ and SSRs $\left(F_{\mathrm{ST}}=0.186\right)$. Analysis of molecular variance showed that a high level of genetic diversity existed for ISSRs and SSRs within populations (62 and 83\%, respectively), rather than among populations (38 and 17\%, respectively). Cluster analysis divided the 3 populations in 2 groups, with the population originating from the island of Crete forming 1 group, while the populations from north Greece (Taxiarchis) and central Greece (Pertouli) were clustered in a 2nd group. In general, the results indicate that SSRs are more informative compared to ISSRs about the genetic variation within a population, whereas the ISSRs were more informative about the genetic diversity among populations However, a similar trend in diversity (genotypic and phenotypic) was observed in the morphological traits and microsatellite-based (SSR/ISSR) markers at the locations studied.

Key words: Cocksfoot; Fodder crop; Genotypic variation; Molecular markers; Phenotypic variation

\section{INTRODUCTION}

Dactylis glomerata L. (Orchardgrass, Cocksfoot, or Cocksfoot Grass), is a widespread, highly cross-pollinated, cool-season perennial grass, that is naturally distributed throughout Europe, including the Mediterranean basin, West and Central Asia, and north Africa. It is an important fodder crop of high agronomic value for the Mediterranean region and for other regions with a Mediterranean-like climate. D. glomerata is a very diverse, complex species that is spread over a wide range of habitats (Lumaret, 1997) with varying water availability, temperature, and physiogeographic conditions.

Germplasm collections from natural populations of agriculturally important plant species have been widely used for the development of improved varieties. Morphological traits and molecular markers may be used for the evaluation of genetic resources, and for the study of prebreeding and breeding germplasms. Morphological traits assess phenotypic variation in growing environments, and are used as tools for the indirect analysis of genetic diversity. In comparison, molecular markers are used for the direct analysis of genetic diversity, because they are reproducible, reliable, and independent from (i.e., not influenced by) environmental conditions. The genetic diversity of D. glomerata populations has been studied using morphological traits (Borrill, 1978), allozymes (Garcia and Lindner, 1998), chloroplast DNA (Sahuquillo and Lumaret, 1999), RAPD markers (Metin et al., 2004), and AFLP markers (Peng et al., 2008).

SSRs, or microsatellites, are routinely used for studies focused on population genetics, because they are easy to use and are highly reproducible, in addition to exhibiting co-dominant inheritance and high polymorphism (Diaz et al., 2006). Recently, a microsatellite-based method has been developed, Inter Simple Sequence Repeats (ISSRs), which involves the PCR amplification of DNA by a single 16-18-bp-long primer composed of a repeated sequence. This approach is highly reproducible and has relatively low cost (Bornet and Branchard, 2001). ISSR analysis has been used to assess the genetic diversity of a large number of plant species, including Lolium spp (Dinelli et al., 2004) and Cynodon dactylon (Wang et al., 2013). Both SSRs and ISSRs are powerful and useful tools for genetic studies and have been used in several plant species; however, at present, reports remain 
limited about their use in studies of D. glomerata populations (Litrico et al., 2009; Xie et al., 2010, 2012).

D. glomerata is widespread from low elevation dry grasslands to high elevation pseudoalpine grasslands in Greece. Nevertheless, there is a complete lack of information about the diversity and structure of the Greek populations of this species. This study aimed to assess morphological differences among and within natural populations of $D$. glomerata growing in contrasting environments. In addition, the comparative effectiveness of SSR and ISSR molecular markers in the genetic study of natural $D$. glomerata populations was evaluated.

\section{MATERIAL AND METHODS}

\section{Plant material and morphological traits}

Three natural populations were sampled from 3 geographically separate locations in north, central, and south Greece (Table 1). At each location, seeds were randomly collected from 72 plants of $D$. glomerata from 3 sites (accessions) separated by a distance of approximately 2 km (i.e. 24 plants from each site) (Table 1).

\begin{tabular}{|c|c|c|c|c|c|c|c|c|c|c|c|c|}
\hline \multirow[t]{3}{*}{ Code } & \multirow[t]{3}{*}{ Geographic localities } & \multicolumn{2}{|c|}{ Geographic data } & \multicolumn{3}{|c|}{ Climatic data } & \multicolumn{4}{|c|}{ Collection sites } & \multicolumn{2}{|c|}{ Sample size } \\
\hline & & \multirow[t]{2}{*}{ Latitude } & \multirow[t]{2}{*}{ Longitude } & \multicolumn{2}{|c|}{$\begin{array}{c}\text { Temperature }\left({ }^{\circ} \mathrm{C}\right) \\
\text { mean annual }\end{array}$} & \multirow{2}{*}{$\begin{array}{l}\text { Precipitation } \\
\text { mean annual } \\
\quad(\mathrm{mm})\end{array}$} & \multirow{2}{*}{\multicolumn{2}{|c|}{$\begin{array}{l}\text { Altitude } \\
\text { (m) }\end{array}$}} & \multirow[t]{2}{*}{ Habitat } & \multirow[t]{2}{*}{$\begin{array}{l}\text { Management } \\
\text { grazing }\end{array}$} & \multirow[t]{2}{*}{$\begin{array}{l}\text { Morphological } \\
\text { traits }\end{array}$} & \multirow[t]{2}{*}{$\begin{array}{c}\text { Molecular } \\
\text { analysis }\end{array}$} \\
\hline & & & & Max & Min & & & & & & & \\
\hline \multirow[t]{3}{*}{ Tax } & \multirow[t]{3}{*}{ Taxiarchis North Gr. } & \multirow[t]{3}{*}{$40^{\circ} 23^{\prime}$} & \multirow[t]{3}{*}{$23^{\circ} 28^{\prime}$} & \multirow[t]{3}{*}{15} & \multirow[t]{3}{*}{5} & \multirow[t]{3}{*}{800} & 1 & 800 & $\mathrm{OF}^{1}$ & Low & 24 & \multirow[t]{3}{*}{10} \\
\hline & & & & & & & 2 & 750 & $\mathrm{OF}$ & Moderate & 24 & \\
\hline & & & & & & & 3 & 650 & $\mathrm{OF}$ & Moderate & 24 & \\
\hline \multirow[t]{3}{*}{ Per } & \multirow[t]{3}{*}{ Pertouli Central Gr. } & \multirow[t]{3}{*}{$39^{\circ} 35^{\prime}$} & \multirow[t]{3}{*}{$21^{\circ} 32^{\prime}$} & \multirow[t]{3}{*}{13} & \multirow[t]{3}{*}{3} & \multirow[t]{3}{*}{1300} & 1 & 1600 & $\mathrm{PG}^{2}$ & Moderate & 24 & \multirow[t]{3}{*}{12} \\
\hline & & & & & & & 2 & 1300 & $\mathrm{FF}^{3}$ & Low & 24 & \\
\hline & & & & & & & 3 & 1100 & $\mathrm{G}^{4}$ & Heavy & 24 & \\
\hline \multirow[t]{3}{*}{ Cre } & \multirow[t]{3}{*}{ Crete South Gr. } & \multirow[t]{3}{*}{$35^{\circ} 8^{\prime}$} & \multirow[t]{3}{*}{$25^{\circ} 30^{\prime}$} & \multirow[t]{3}{*}{28} & \multirow[t]{3}{*}{5} & 800 & 1 & 1300 & $\mathrm{Ph}^{5}$ & Heavy & 24 & 8 \\
\hline & & & & & & & 2 & 1200 & $\mathrm{Ph}$ & Heavy & 24 & \\
\hline & & & & & & & 3 & 1000 & $\mathrm{Ph}$ & Heavy & 24 & \\
\hline
\end{tabular}

${ }^{1}$ Oak forest (Quercus frainetto), Dactylis glomerata L., Brahypodium sylvaticum (Hudso) P. Beauv., Carex sp; ${ }^{2}$ Pseudoalpine grassland, Lotus corniculatus L., Dactylis glomerata L., Phleum montanum (L.) K. Koch; ${ }^{3}$ Fir forest (Abies borisi regis), Dactylis glomerata L., Trifolium sp., Brahypodium sp; ${ }^{4}$ Grassland, Lolium perenne (L.), Platango lagopus (L), Trifolium repens (L.); ${ }^{5}$ Phryganic intermixed with herbaceous species, Sarcopoterium spinosum (L.) Spach., Euphorbia acanthothamnos, Heldr. Sart ex Boiss, Dactylis glomerata L., Hordeum bulbosum L., Cynodon dactylon (L.) Pers.

The field experiment for the morphological study was carried out on the farm of Aristotle University of Thessaloniki, north Greece $\left(40^{\circ} 32^{\prime} \mathrm{N}, 22^{\circ} 59^{\prime} \mathrm{E}\right)$, at an elevation of about $10 \mathrm{~m}$ above sea level (a.s.l.). The seeds collected from the 72 plants from each location were planted in separate plastic pots that had been filled with a commercial growing medium (TKS 2: Floragard, Oldenburg, Germany: $\mathrm{pH} 5.2-6.0, \mathrm{~N} 18-280 \mathrm{mgl}^{-1}, \mathrm{P}_{2} \mathrm{O}_{5} 210-350 \mathrm{mgl}^{-1}$ and $\mathrm{K}_{2} \mathrm{O} 280-460 \mathrm{mgl}^{-1}$ ). The pots were placed in a greenhouse for 2 months. The seedlings were transplanted to a 6 plant row plots in the field of the research station. Plots were arranged in a randomized complete-block design (block to the locations) with 4 replications, i.e., 6 plants per row $\mathrm{x} 4$ replications $\mathrm{x} 3$ sites per location, a total of 72 plants per geographic location.

The number of reproductive tillers was measured for each plant. Three reproductive 
tillers for each plant that were heading at the same time were randomly selected. Each tiller was scored for the following morphological traits: height $(\mathrm{cm})$, tiller and flag leaf blade width (visually on a scale 1 narrow to 3 broad), length of the panicle $(\mathrm{cm})$, length of first panicle's internode $(\mathrm{cm})$, second branch length (glomerulus + pedicel) $(\mathrm{cm})$, and second pedicel length $(\mathrm{cm})$. The mean of the 3 measurements were calculated for each plant. One-way analysis of variance (ANOVA) of the data and principal component analysis (PCA) was performed using the PASW Statistics 18 software (SPSS Inc., Chicago, IL, USA), to determine differences among the locations and accessions at each location. The LSD at the 0.05 probability level was used to detect the differences among means (Steel and Torrie, 1980). The data were also used to generate eigenvalues, the percentage of variation accumulated by PCA, and the load coefficient values between the original characteristics and respective PCA. The first 2 principal components, which accounted for the highest variation, were used to plot the 2-dimensional dispersion of the accessions.

\section{Molecular markers}

\section{DNA extraction and PCR}

A sample, of 8-12 individual plants was randomly collected from each geographic location, and was subjected to further microsatellite (SSR/ISSR) analysis (Table 1). Total genomic DNA was isolated using the procedure described by Doyle and Doyle (1987). The amount of DNA was quantified by a UV-spectrophotometer (Eppendorf Biophotometer, Hamburg, Germany). Samples were then diluted to a $20 \mathrm{ng} / \mu \mathrm{L}$ working concentration.

Polymerase chain reactions (PCR) for SSR and ISSR analysis were performed in a total volume of $25 \mu \mathrm{L}$, containing $20 \mathrm{ng}$ total cellular DNA, $200 \mathrm{mM}$ of each dNTP, $2 \mathrm{mM}$ $\mathrm{MgCl}_{2}, 40$ pmol of primers, $2.5 \mu \mathrm{L}$ 10xTaq DNA polymerase buffer, and 1U DyNAzyme II DNA polymerase (Finnzymes, Espoo, Finland) or KAPA Taq DNA polymerase.

\section{SSR amplification and ISSR amplification}

Seven primer pairs were used for the SSR analysis, following the method of Litrico et al. (2009). PCR amplifications were performed in a PTC 200 PTC 200 (MJ Research Inc, MA, USA) as follows: initial denaturation of $3 \mathrm{~min}$ at $94^{\circ} \mathrm{C}$ followed by 40 cycles of $30 \mathrm{~s}$ at $94^{\circ} \mathrm{C}$, annealing at $45^{\circ} \mathrm{C}$ for $45 \mathrm{~s}$, and extension at $72^{\circ} \mathrm{C}$ for $30 \mathrm{~s}$. A 7 min step at $72^{\circ} \mathrm{C}$ was programmed as a final extension. PCR products were electrophoresed on metaphor $2 \%+2 \%$ agarose gels in $1 \mathrm{X} \mathrm{TBE}$ buffer at $8^{\circ} \mathrm{C}$ in a cold room, and visualized using a transilluminator. Selected ISSR primers (University of British Columbia, primer set wo. 9, Vancouver, BC, Canada) were used for PCR amplification. Binary data points denote the presence/absence of each distinguishable band across all samples for the same primer, in both replicate sets of amplifications. PCR amplifications were performed in a PTC 200 (MJ Research Inc) as follows: an initial step of $5 \mathrm{~min}$ at $94^{\circ} \mathrm{C}$, followed by 35 cycles of $30 \mathrm{~s}$ at $94^{\circ} \mathrm{C}$, for denaturation, $90 \mathrm{~s}$ at $45-60^{\circ} \mathrm{C}$ (depending on the primer used) for annealing, and $90 \mathrm{~s}$ at $72^{\circ} \mathrm{C}$, for elongation. $\mathrm{A}$ 5 min step at $72^{\circ} \mathrm{C}$ was programmed as the final extension. Amplification products were separated by electrophoresis on 1.5\% agarose gel, and stained with ethidium bromide. A 100-bp or 1-Kb DNA ladder (Invitrogen, Carlsbad, CA, USA) was used as a size marker. Gel images 
were placed in a UVItec Transilluminator (UVItec Limited, Cambridge, United Kingdom) and analyzed using UVIDoc software UVIDocMw version 99.04 (UVItec, Limited).

\section{Data analysis}

The percentage of polymorphic loci (P), effective numbers of alleles $\left(N_{\mathrm{E}}\right)$, gene diversity (expected heterozygosity, $H_{\mathrm{E}}$ ), Shannon's diversity index (I), gene differentiation coefficients $\left(G_{S T}\right.$ for ISSR and $F_{S T}$ for SSR), and unbiased genetic distances according to (Nei, 1978) were calculated using PopGene32 (Yeh et al., 1999) for both markers. ISSRs are dominant markers, with each band representing the phenotype at a single biallelic locus. Only bands that could be unambiguously scored were used in the analysis. ISSR amplified bands were scored for band presence (1) or absence (0), and a binary qualitative data matrix was formed. In addition, allelic richness (A), private allelic richness $\left(p_{A R}\right)$ alleles (which are unique to a particular population), and the inbreeding coefficient $\left(F_{\mathrm{IS}}\right)$ within and among populations was calculated from the SSR data, using the hierarchical rarefaction method available in HP-RARE (Kalinowski, 2005). As null alleles were suspected to be present at some loci, allelic frequency estimation and comparison between observed and HardyWeinberg expected heterozygote frequencies were computed by the maximum likelihood method (Kalinowski and Taper, 2006).

The FSTAT program was used to calculate the $F_{S T}$ (Cockerham and Weir, 1984) of SSR markers across all populations. Pairwise population differentiation was evaluated by $\mathrm{F}_{\text {ST }}$ using FSTAT (Goodman, 1997). Statistical significance of the estimates was determined with 1000 randomizations. Means and significant values over loci, populations, and subdivisions were obtained by jackknifing. GENEPOP (Raymond and Rousset, 1995) online version (http:// genepop.curtin.edu.au/) was used to calculate the inbreeding coefficient $\left(F_{\text {IS }}\right)$ for each locus in each population, and to test for linkage disequilibrium between all pairs of loci. Conformance to Hardy-Weinberg equilibrium was determined by assessing the significance of the $F_{\text {IS }}$ values by Fisher's exact tests implemented in GENEPOP, with specified Markov chain parameters of 5000 dememorization steps, followed by 1000 batches of 5000 iterations per batch. The sequential Bonferroni's correction was applied to obtain critical confidence limits for multiple comparisons, with an initial probability of $\mathrm{P}=0.05$.

The hierarchical distribution of genetic variation among and within populations was also characterized by analysis of molecular variance (AMOVA) (Excoffier et al., 1992; Michalakis and Excoffier, 1996) using the GENALEX 6 software (Peakall and Smouse, 2006), with variation being examined among and within populations. The tests were implemented using estimates of $\Phi_{\mathrm{ST}}$, based on distances calculated from allelic data. Tests of significance were performed using 9999 permutations within the total dataset.

\section{Clustering and assignment methods}

An unweighted pair group method with arithmetic mean (UPGMA) dendrogram based on Nei's (1978) unbiased genetic distances was constructed for both SSR and ISSR markers, to illustrate relationships among populations (Nei, 1973). Principal coordinate analysis (PCO) was used to visualize the genetic structure of each dataset. The analyses of the SSR and ISSR data sets were executed in GENALEX (Peakall and Smouse, 2006). 


\section{RESULTS}

\section{Morphological analysis}

Analysis of variance (ANOVA) revealed significant variation among the studied geographic locations $(\mathrm{P} \leq 0.05)$ for 7 of the 8 morphological traits. The number of reproductive tillers per plant was not significantly different among the populations. Taxiarchis had significantly higher values for plant height, leaf and stem width, length of panicle, and length of panicle's first internode compared to the other regions. In comparison, all parameters at Crete were significantly lower compared to the other 2 locations. Similarly, the second branch and second pedicel of panicles was significantly longer at Taxiarchis compared to the other 2 locations, whereas there were not significant differences between Pertouli and Crete for these 2 parameters (Table 2).

\begin{tabular}{|c|c|c|c|c|c|c|c|c|c|c|}
\hline \multirow[t]{2}{*}{ Morphological traits } & \multirow[t]{2}{*}{ Location } & \multicolumn{3}{|c|}{ Accessions } & \multirow[t]{2}{*}{ Mean } & \multirow[t]{2}{*}{ CV (\%) } & \multicolumn{4}{|c|}{$\mathrm{F}$ values/Sig. } \\
\hline & & 1 & 2 & 3 & & & Loca & & Accessi & cation \\
\hline \multicolumn{11}{|l|}{ Vegetative traits } \\
\hline \multirow[t]{3}{*}{ Height (cm) } & Tax & 35 & 33 & 34 & $34 \pm 0.5^{\mathrm{a}}$ & 12 & 464.35 & $* *$ & 0.871 & NS \\
\hline & Per & 29 & 32 & 32 & $31 \pm 0.5^{b}$ & 13 & & & 4.838 & $* *$ \\
\hline & Cre & 18 & 17 & 15 & $17 \pm 0.3^{\mathrm{c}}$ & 15 & & & 10.609 & $* *$ \\
\hline \multirow[t]{3}{*}{ Leaf width } & Tax & 3.3 & 3.3 & 3.1 & $3.3 \pm 0.07^{\mathrm{a}}$ & 18 & 173.17 & $* *$ & 1.533 & NS \\
\hline & Per & 2.3 & 3.0 & 2.9 & $2.7 \pm 0.09^{\mathrm{b}}$ & 30 & & & 5.039 & $* *$ \\
\hline & Cre & 1.4 & 1.3 & 1.3 & $1.3 \pm 0.06^{\mathrm{c}}$ & 36 & & & 0.416 & NS \\
\hline \multirow[t]{3}{*}{ Stem width } & Tax & 3.2 & 3.6 & 2.9 & $3.2 \pm 0.08^{\mathrm{a}}$ & 20 & 153.43 & $* *$ & 9.659 & $* *$ \\
\hline & Per & 2.2 & 2.5 & 2.6 & $2.5 \pm 0.09^{\mathrm{b}}$ & 30 & & & 2.265 & NS \\
\hline & Cre & 1.5 & 1.5 & 1.2 & $1.4 \pm 0.06^{\mathrm{c}}$ & 35 & & & 2.589 & NS \\
\hline \multicolumn{11}{|l|}{ Reproductive traits } \\
\hline \multirow[t]{3}{*}{ NoRT plant $^{-1}$} & Tax & 15 & 14 & 11 & $13 \pm 0.6$ & 39 & 1.15 & NS & 3.328 & NS \\
\hline & Per & 12 & 15 & 17 & $14 \pm 0.8$ & 48 & & & 2.339 & NS \\
\hline & Cre & 14 & 13 & 13 & $13 \pm 0.7$ & 44 & & & 0.556 & NS \\
\hline \multirow[t]{3}{*}{ PL (cm) } & Tax & 7.0 & 8.1 & 7.3 & $7.5 \pm 0.2^{\mathrm{a}}$ & 20 & 99.26 & $* *$ & 4.157 & $* *$ \\
\hline & Per & 3.6 & 5.6 & 5.5 & $4.8 \pm 0.2^{\mathrm{b}}$ & 28 & & & 24.465 & $* *$ \\
\hline & Cre & 5.3 & 5.1 & 2.9 & $4.5 \pm 0.2^{\mathrm{c}}$ & 29 & & & 79.270 & $* *$ \\
\hline \multirow[t]{3}{*}{ LFI (panicle) (cm) } & Tax & 2.6 & 2.8 & 2.8 & $2.7 \pm 0.07^{\mathrm{a}}$ & 22 & 88.15 & $* *$ & 0.802 & NS \\
\hline & Per & 1.2 & 1.9 & 1.7 & $1.8 \pm 0.07^{\mathrm{b}}$ & 37 & & & 10.670 & $* *$ \\
\hline & Cre & 1.8 & 1.8 & 0.8 & $1.5 \pm 0.08^{\mathrm{c}}$ & 44 & & & 38.061 & $* *$ \\
\hline \multirow[t]{3}{*}{ SBL (cm) } & Tax & 3.5 & 3.7 & 3.7 & $3.6 \pm 0.10^{\mathrm{a}}$ & 24 & 139.5 & $* *$ & 0.679 & NS \\
\hline & Per & 1.5 & 2.4 & 2.0 & $2.0 \pm 0.07^{b}$ & 32 & & & 16.809 & $* *$ \\
\hline & $\mathrm{Cre}$ & 2.2 & 2.0 & 1.1 & $1.8 \pm 0.08^{\mathrm{b}}$ & 37 & & & 34.130 & $* *$ \\
\hline \multirow[t]{3}{*}{ SPL $(\mathrm{cm})$} & Tax & 1.6 & 1.8 & 1.9 & $1.8 \pm 0.07^{\mathrm{a}}$ & 35 & 152.7 & $* *$ & 1.854 & NS \\
\hline & Per & 0.4 & 0.8 & 0.5 & $0.6 \pm 0.05^{b}$ & 67 & & & 10.005 & ** \\
\hline & Cre & 0.8 & 0.7 & 0.2 & $0.6 \pm 0.06^{\mathrm{b}}$ & 70 & & & 23.043 & $* *$ \\
\hline
\end{tabular}

NoRT $=$ number of reproductive tillers; $\mathrm{PL}=$ panicle length; $\mathrm{LFI}($ panicle $)=$ length of first internode; $\mathrm{SBL}=$ second branch length; SPL = second pedicel length; $\mathrm{CV}=$ coefficient of variation significance at ANOVA and means $* * \mathrm{P} \leq 0.05 ; \mathrm{NS}=$ not significant at ANOVA. Means followed by different letters for the same morphological trait significantly differ $(\mathrm{P} \leq 0.05)$.

High differentiation among the accessions was observed at Pertouli and Crete, where there were significant differences among accessions for 7 and 5 of the 8 morphological traits, respectively (Table 2). Compared to the other accessions, accession 1 in Pertouli and 3 in Crete (located at higher and lower elevations, respectively) had consistently lower values for all morphological traits. The lowest differentiation was observed in Taxiarchis, where there were 
significant differences among the accessions for just 2 of the 8 morphological traits (Table 2), namely stem width and panicle length.

The reproductive morphological traits generally revealed higher variability for the coefficient of variation (CV) estimation compared to vegetative morphological traits (Table 2). In particular, the CV for reproductive traits ranged from $70 \%$ to $20 \%$, whereas the $\mathrm{CV}$ for vegetative traits ranged from $36 \%$ to $12 \%$. Among the populations studied, Crete had the highest CV values for all morphological traits, while Taxiarchis had the lowest. The only exception was the number of reproductive tillers, for which Pertouli had the highest CV values.

The first 3 principal components (PCs) with Eigen values $>1.0$ cumulatively contributed about $99 \%$ of the total variation among the accessions for the 8 morphological traits (Table 3 ). The PC1, PC2, and PC3 accounted for 50\%, 36\%, and 13\%, respectively, of the total variation. The variation in PC1 was mainly associated with reproductive traits, i.e., the panicle and the panicle's first internode length, the second branch, and the second pedicel of the panicle. The predominant traits in PC2 were the vegetative traits, i.e., plant height and leaf and stem width. The predominant traits in PC3 were the number of reproductive tillers per plant. The length of panicle's first internode for the PC1 and the plant height for the PC2 were more representative compared to the other morphological traits, because they were less correlated with the other 2 components. According to the scatter diagram of the first 2 principal components (Figure 1), accessions of Taxiarchis and Pertouli were located on the positive side of PC1, while accessions of Crete were located on the negative side. However, the accessions of Taxiarchis were distributed on the positive side of PC2, while the accessions of Pertouli were distributed on the negative side, and the accessions of Crete were distributed between the other two locations.

\begin{tabular}{|c|c|c|c|c|c|c|c|c|}
\hline & 1 & 2 & 3 & 4 & 5 & 6 & 7 & 8 \\
\hline Height & 0.348 & 0.928 & 0.099 & -0.066 & -0.012 & -0.062 & -0.006 & 0.000 \\
\hline Leaf width & 0.422 & 0.889 & 0.159 & -0.004 & 0.016 & 0.076 & 0.008 & 0.000 \\
\hline Stem width & 0.568 & 0.789 & 0.115 & 0.204 & -0.002 & 0.003 & 0.002 & 0.000 \\
\hline No panicles & -0.050 & 0.150 & 0.987 & 0.003 & -0.004 & 0.000 & 0.000 & 0.000 \\
\hline Length panicle & 0.913 & 0.371 & 0.124 & 0.044 & -0.102 & 0.005 & 0.010 & -0.004 \\
\hline Length first internode & 0.930 & 0.360 & -0.001 & -0.029 & -0.041 & -0.039 & 0.043 & -0.003 \\
\hline Second branch length & 0.909 & 0.409 & -0.045 & 0.000 & 0.061 & 0.016 & 0.009 & 0.015 \\
\hline Second pedicel length & 0.911 & 0.355 & -0.182 & 0.036 & 0.091 & 0.032 & 0.030 & -0.007 \\
\hline Eigenvalue & 3.979 & 2.857 & 1.074 & 0.050 & 0.025 & 0.013 & 0.003 & 0.000 \\
\hline$\%$ variance & 49.733 & 35.716 & 13.421 & 0.624 & 0.307 & 0.157 & 0.038 & 0.004 \\
\hline Cumulative \% & 49.733 & 85.449 & 98.870 & 99.493 & 99.801 & 99.958 & 99.996 & 100.000 \\
\hline
\end{tabular}

Rotation component matrix $=$ Varimax with kaiser normalization.

\section{Microsatellite-based (SSR/ISSR) markers analysis}

\section{SSR and ISSR analysis}

The selected SSR primers generated an average of 6 alleles per locus, ranging from 2 (NFFA036) to 10 (NFFA045). The genetic differentiation among $F_{S T}$ population parameters also varied among loci, ranging from 0.014 (NFFA045) to 0.432 (NDPK) (Table 4). In comparison, a total of 105 bands were obtained from the 6 selected ISSR primers. The number of bands ranged from 15 bands (816 and 827) to 21 bands (841), with an average of 17.5 bands per primer (Table 5). 


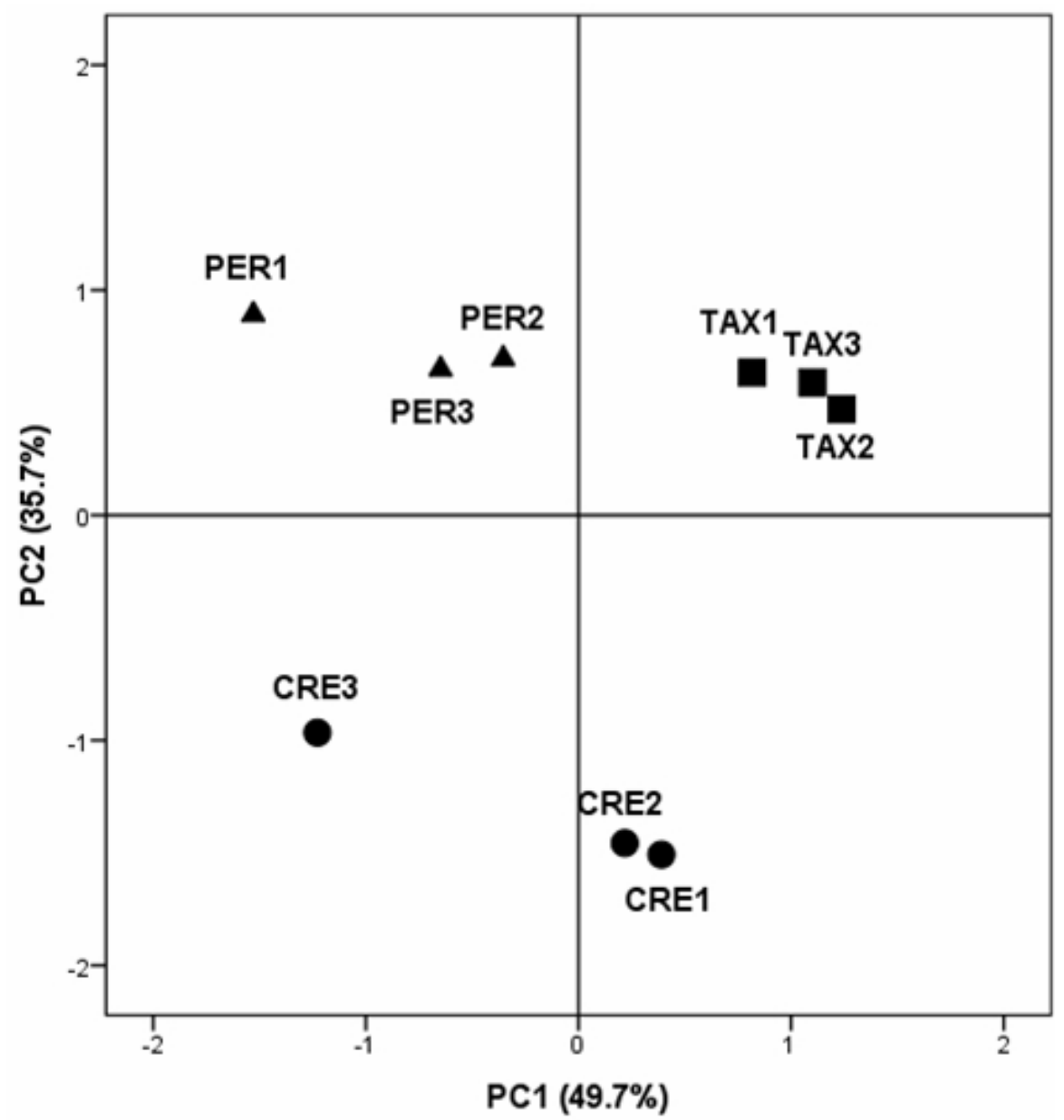

Figure 1. Scatter plot of the first and second principal components based on the morphological traits of Dactylis glomerata accessions from Taxiarchis (Tax), Pertouli (Per), and Crete (Cre).

In general, relatively high levels of genetic variation were observed at both the species level $\left(\mathrm{P}=100 \%, \mathrm{I}=0.657, H_{\mathrm{E}}=1.360\right)$ and at the location level $\left(\mathrm{P}=95.24 \%, \mathrm{I}=0.985, H_{\mathrm{E}}\right.$ $=0.538$ ) based on SSRs (Table 6). Among the locations studied, Crete and Pertouli exhibited the highest level of polymorphism $(\mathrm{P}=100 \%)$ and Taxiarchis the lowest $(\mathrm{P}=85.71 \%)$. In addition, Crete showed slightly higher levels of genetic variation for the Shannon's information index, and had a higher number of private alleles (36.36\%) compared to Pertouli and Taxiarchis (Table 6). Genetic variation based on ISSR markers was also relatively high at both the species $\left(\mathrm{P}=100 \%, N_{\mathrm{E}}=1.423, \mathrm{I}=0.402, H_{\mathrm{E}}=0.257\right)$ and location level $\left(\mathrm{P}=61.33, N_{\mathrm{E}}=\right.$ $1.307, \mathrm{I}=0.282, H_{\mathrm{E}}=0.183$ ) (Table 6). Among the locations studied, Pertouli exhibited the highest level of polymorphism $(\mathrm{P}=72 \%)$ and Taxiarchis the lowest $(\mathrm{P}=54 \%)$. The Pertouli location had the highest level of genetic variation for the Shannon's information index, while Taxiarchis the lowest (Table 6). 
P. Madesis et al.

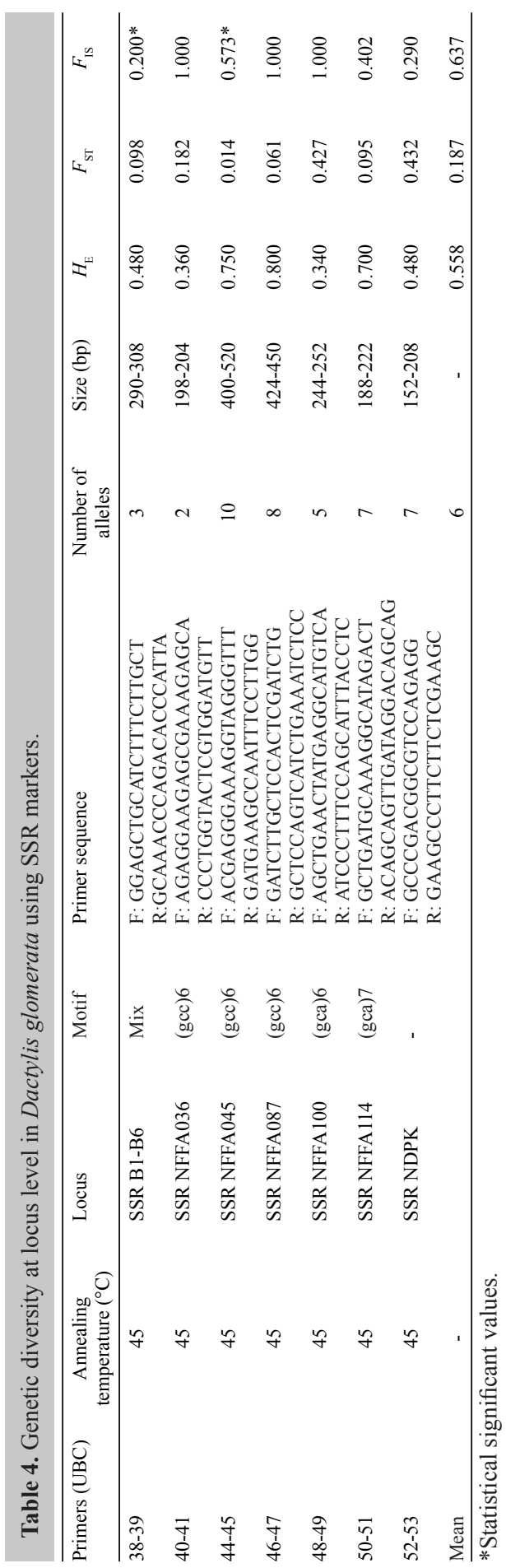


Table 5. Genetic diversity at locus level in Dactylis glomerata using ISSR markers.

\begin{tabular}{lcccc}
\hline Primer (UBC) & $\begin{array}{c}\text { Annealing temperature } \\
\left({ }^{\circ} \mathrm{C}\right)\end{array}$ & $\begin{array}{c}\text { Fragment size } \\
\text { range }\end{array}$ & $\begin{array}{c}\text { Fraction polymorphic } \\
\text { fragments }\end{array}$ & $\begin{array}{c}\text { Percentage polymorphism } \\
(\%)\end{array}$ \\
\hline 811 & 52 & $500-2400$ & $17 / 17$ & 100 \\
816 & 55 & $800-3100$ & $15 / 17$ & 88.2 \\
827 & 55 & $500-2200$ & $15 / 15$ & 100 \\
834 & 55 & $500-2600$ & $16 / 16$ & 100 \\
841 & 52 & $600-3850$ & $21 / 23$ & 91.3 \\
860 & 52 & $600-2600$ & $17 / 17$ & 100 \\
Mean & - & - & & 96.5 \\
\hline
\end{tabular}

Table 6. Genetic diversity at population and species level in Dactylis glomerata.

\begin{tabular}{|c|c|c|c|c|c|c|c|c|c|c|c|c|c|c|}
\hline \multirow[b]{2}{*}{ Populations } & \multicolumn{6}{|c|}{ SSR } & \multirow[t]{2}{*}{$F_{\text {IS }}$} & \multirow[t]{2}{*}{$F_{\mathrm{ST}}$} & \multirow[t]{2}{*}{$N_{\mathrm{E}}$} & \multicolumn{5}{|c|}{ ISSR } \\
\hline & $N_{\mathrm{E}}$ & I & $H_{\mathrm{E}}$ & $\mathrm{P}(\%)$ & A & PrA & & & & I & $H_{\mathrm{E}}$ & $\mathrm{P}(\%)$ & PrB & $G_{\mathrm{ST}}$ \\
\hline Crete & 3.287 & 1.235 & 0.624 & 100.00 & 3.158 & 12 & 0.517 & & 1.313 & $0.278^{*}$ & 0.183 & 58.00 & 11 & \\
\hline Taxiarchis & 2.202 & 0.850 & 0.496 & 85.71 & 3.143 & 2 & 0.742 & & 1.230 & $0.223 *$ & 0.141 & 54.00 & 7 & \\
\hline Pertouli & 2.346 & 0.872 & 0.494 & 100.00 & 4.635 & 4 & 0.688 & & 1.379 & $0.346^{*}$ & 0.226 & 72.00 & 12 & \\
\hline Mean & 2.612 & 0.985 & 0.538 & 95.24 & 3.645 & 6 & 0.649 & 0.186 & 1.307 & 0.282 & 0.183 & 61.33 & 10 & 0.291 \\
\hline Species level & 1.787 & 0.657 & 1.360 & 100 & & & 0.637 & & 1.423 & 0.402 & 0.257 & 100 & & \\
\hline
\end{tabular}

$\mathrm{P}=$ percentage of polymorphic loci; $H_{\mathrm{E}}=$ expected heterozygosity; I = Shannon's index; $F_{\mathrm{ST}}=$ gene differentiation coefficient (SSR); $G_{\text {st }}=$ gene differentiation coefficient (ISSR); $F_{\text {IS }}=$ inbreeding coefficient; $N_{\mathrm{E}}$ : effective number of alleles; $\mathrm{A}=$ allelic richness; $\operatorname{PrB}=$ private bands; $\operatorname{Pr} \mathrm{A}=$ private alleles. Significant deviations from zero are indicated by asterisks $(* \mathrm{P}<0.05)$.

Genetic variability of $D$. glomerata mainly existed within rather than among the tested locations $\left(F_{\mathrm{ST}}=0.186, G_{\mathrm{ST}}=0.291\right)$ (Table 6 ). Supporting this result, AMOVA analysis (Table 7) revealed that a higher percentage of variation was observed within (83\%) compared to among (17\%) locations for SSRs. Similarly, based on ISSRs, 38\% of the total genetic variation was attributed to differences among locations, and the rest (62\%) was attributed to differences within locations (Table 7).

Table 7. Analysis of molecular variance (AMOVA) results of three populations based on ISSR and SSR markers.

\begin{tabular}{|c|c|c|c|c|c|c|c|}
\hline & Source of variation & d.f. & SSD & Variance component & Total variance $(\%)$ & $\Phi$-Statistics & Pvalue \\
\hline \multirow[t]{3}{*}{$\overline{\mathrm{SSR}}$} & Among populations & 2 & 44.542 & 1.509 & 17 & \multirow{3}{*}{$\Phi_{\mathrm{ST}}=0.170$} & \multirow{3}{*}{$<0.001$} \\
\hline & Within populations & 27 & 199.292 & 7.381 & 83 & & \\
\hline & Total & 29 & 243.833 & 8.890 & 100 & & \\
\hline \multirow[t]{3}{*}{ ISSR } & Among populations & 2 & 151.950 & 6.616 & 38 & \multirow{3}{*}{$\Phi_{\mathrm{ST}}=0.382$} & \multirow{3}{*}{$<0.001$} \\
\hline & Within populations & 27 & 288.850 & 10.698 & 62 & & \\
\hline & Total & 29 & 440.800 & 17.314 & 100 & & \\
\hline
\end{tabular}

The UPGMA tree based on Nei's (1978) unbiased genetic identity for all populations using the SSR markers revealed 2 distinct clusters (Figure 2A), with Pertouli in 1 cluster, while Crete and Taxiarchis were grouped in the second cluster. The UPGMA tree based on Nei's (1978) unbiased genetic identity for all locations using ISSR markers also revealed 2 distinct groups (Figure 2B); however, in this instance, Crete was in 1 cluster, while Pertouli and Taxiarchis were in the other cluster. 
A) SSR

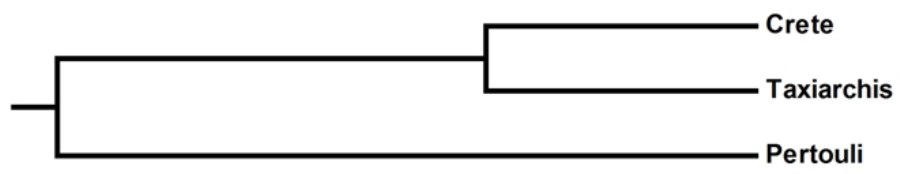

B) ISSR
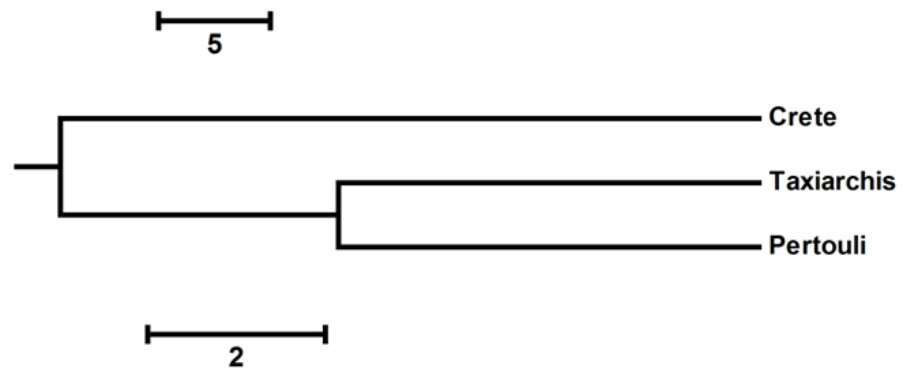

Figure 2. UPGMA dendrogram, derived from Nei's (1978) unbiased genetic distances, showing the relationships among five examined populations of Dactylis glomerata using SSR A. and ISSR B. data sets. Branch lengths are proportional to genetic distances.

The PCA scatter plot based on SSR markers showed much more vague borders among the 3 regions (Figure 3A), with individuals from all three locations being mixed. In comparison, the PCA scatter plot based on ISSR markers generated 3 major clusters (Figure 3B), in which the 3 locations were clearly separated.
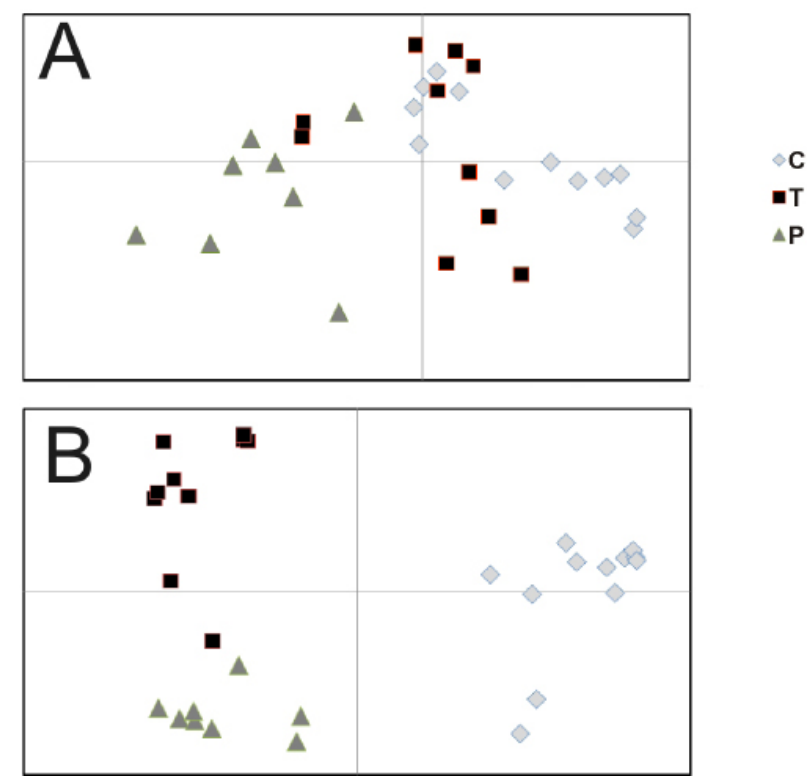

Figure 3. Scatter plots of the first and second principal components based on the molecular variation of both SSR and ISSR markers for 30 individuals of Dactylis glomerata: A. SSR data components 1 and 2 B. ISSR data components 1 and 2. Crete $=(\mathrm{C})$, Taxiarchis $=\mathbf{\square}(\mathrm{T})$, Pertouli $=\mathbf{\Delta}(\mathrm{P})$. 


\section{DISCUSSION}

\section{Morphological analysis}

Morphological analysis clearly separated the accessions of $D$. glomerata collected from north, central, and south Greece. Individuals from the north (Taxiarchis) were taller with broader leaves and stems and longer panicles compared to individuals from the central and south. In comparison, the accessions from the south (Crete Island) had the shortest plants with the narrowest leaves and stems and the shortest panicles.

This differentiation might be attributed to the species mating system, gene flow, genetic drift, long term evolutionary history (Hogbin and Peakall, 1999), habitat differentiation, or management (Peter-Schmid et al., 2008). In particular, the morphological characteristics of Crete's accessions might reflect adaptation to the dry conditions of the area, particularly during the growing season, or adaptation to the long-term overgrazing of the area (Papanastasis et al., 2002). In general, heavily grazed populations of forage grasses tend to have smaller and more prostrate plants compared to moderately grazed plants (Painter et al., 1993). In comparison, the morphological characteristics of individuals from Taxiarchis and Pertouli appeared to represent forage of higher production and nutritive value compared to individuals from Crete. Indeed, Crete's accessions had the lowest forage production and nutritive value (Parissi et al., 2007) compared to Taxiarchis and Perouli.

The highest phenotypic variation was observed for the accessions from Crete, which might also be considered as a peripheral population of the species, while the lowest phenotypic variation was observed for the accessions from Taxiarchis. Similar results were reported by Volis et al. (1998) for peripheral populations of Hordeum spontaneum, whereas the opposite result was reported by Abebe et al. (2010) for Ethiopian Hordeum vulgare. High phenotypic variation was also detected for the accessions from Pertouli, probably because this area contains a wide variety of habitats, which creates different micro-climatic conditions.

The phenotypic variation of reproductive morphological traits seemed to be higher compared to the vegetative ones. A similar trend was observed in the morphological study of 39 accessions from various geographic locations around the world, although the corresponding $\mathrm{CV}$ values were lower compared to those obtained in the present study (Agriculture Science, 2012). Similarly, the high variance of the first 3 PCs indicates a high degree of phenotypic variation among both vegetative and reproductive traits. However, among the morphological traits studied, the panicle's first internode and plant height seemed to be better descriptors for this D. glomerata germplasm.

\section{Molecular analysis}

Microsatellite SSR and ISSR markers were used to provide an indication of genetic variation of $D$. glomerata from geographic locations in north, central, and south Greece. The results indicated that all 3 locations had relatively high level of genetic variation for polymorphic rates $(\mathrm{P}=100 \%)$ based on both SSR and ISSR markers. Polymorphism in the present study was higher compared to previous reports on SSR variation $(\mathrm{P}=84.63)$ (Xie et al., 2010), ISSR variation ( $\mathrm{P}=86.3$ ) (Xie et al., 2010), and AFLP variation ( $\mathrm{P}=84 \%$ ) (Peng et al., 2008).

The north location (Taxiarchis), which scored the lowest phenotypic variation, also 
exhibited the lowest level of genetic variation based on both SSR and ISSR markers. In comparison, the highest levels of genetic variation were observed at the south location (Crete Island) based on SSRs and at the central location (Pertouli) based on ISSRs. It seems that stressful environments, such as Crete, have higher phenotypic and genetic variation (Badyaev, 2005) compared to favorable environments for the species growing. The similar phenotypic and genetic variation at Pertouli might also be attributed to the variety of habitats in the area. In addition, a higher number of private alleles were detected at Crete compared to the other 2 locations, probably because of geographic isolation facilitating greater differentiation (Wolf et al., 2000). Genetic variability mainly existed within rather than among the tested locations, as shown by AMOVA, based on both SSRs and ISSRs. Similarly, analysis of molecular variation (AMOVA) based on SSRs revealed larger genetic variation within accessions $(65.75 \%)$ and geographical regions $(75.58 \%)$, rather than between them, in the analysis of 16 D. glomerata accessions collected from China, Russia, Kazakhstan, India, and Japan (Xie et al., 2010). In addition, Kölliker et al. (1999) obtained 85\% variability within 3 cultivars of D. glomerata.

The SSR and ISSR data analysis resulted in different relatedness of the locations studied. Based on the SSRs, the 3 locations were clustered into 2 groups, with 1 cluster containing Pertouli, while the other cluster contained Crete with Taxiarchis. However, based on the ISSRs, 1 cluster contained Taxiarchis and Pertouli, while the other cluster contained Crete. It seems that the grouping based on ISSR markers is more reasonable compared to that based on SSRs, as it also corresponds to the morphological analysis.

Higher levels of genetic variation were detected within the 3 locations based on the SSRs, rather than the ISSRs. In comparison, higher differentiation was detected among the populations based on the ISSRs, rather than the SSRs. These results support Davierwala et al. (2000) who reported higher genetic variation within Indian rice varieties for SSRs, in comparison to RAPDs and ISSRs. Furthermore, Huang et al. (2009) also reported low levels of genetic variation within Omphalogramma souliei populations, and remarkable differentiation among populations, based on ISSRs.

The results based on molecular markers are indicative, particularly as the sample size of 10 individuals per location used in this study is considered to be relatively small for detecting the genetic diversity of allogamous species, such as D. glomerata. However, based on Xie et al. (2010), the minimum number of 10 individuals per population proved to be representative because of the high degree of genetic variation in D. glomerata germplasm at the species level. Nevertheless, further study with more individuals from each location, particularly in areas where habitat variation exists, might prove to be beneficial.

\section{Breeding implications}

The introduction of new genetic material is necessary for new releases of cultivars to meet specific cultivation conditions, and to respond to environmental conditions that arise from climate changes. Hence, breeding practices must exploit the genetic variation of the species, with natural populations potentially serving as an important source. The stressful environments and variable habitats occupied by $D$. glomerata populations in this study revealed the highest levels of phenotypic and genotypic variation. This trend was identified by both morphological and microsatellite-based (SSR/ISSR) markers. Furthermore, it seems that $D$. glomerata grown in stressful environments might provide a useful gene pool for adaptation 
traits, whereas more favorable environments might provide a useful gene pool for qualitative traits. However, the high differentiation of the locations indicates that the collection and evaluation of $D$. glomerata's germplasm from different eco-geographical regions that has been subject to different management practices is necessary to maintain high genetic variation for the conservation and breeding of this species. The microsatellite-based (SSR/ISSR) markers were informative and effective in the genetic study of natural D. glomerata populations. In conclusion, it seems that genetic variation in D. glomerata populations within and between geographic locations is better described by SSRs and ISSRs, respectively.

\section{ACKNOWLEDGMENTS}

Research supported by the Institute of Applied Biosciences/CERTH from the General Secretariat of Research and Technology of Greece.

\section{REFERENCES}

Abebe TD, Bauer AM and Leon J (2010). Morphological diversity of Ethiopian barley (Hordeum vulgare L.) in relation to geographic regions and altitudes. Hereditas 147: 154-164.

Agriculture Science (2012). The morphological diversity of SSR marker of Dactylis glomerata L. Available at [http:// www.agrpaper.com] Accessed 3 March 2012.

Badyaev AV (2005). Stress-induced variation in evolution: from behavioural plasticity to genetic assimilation. Proc. Biol. Sci. 272: 877-886.

Bornet B and Branchard M (2001). Nonanchored inter simple sequence repeat (ISSR) markers: Reproducible and specific tools for genome fingerprinting. Plant Mol. Biol. Rep. 19: 209-215.

Borrill M (1978). Evolution and Genetic Resources in Cocksfoot. Station ARWPB (edn) Plant Breeding Station, Aberystwyth.

Cockerham CC and Weir BS (1984). Covariances of relatives stemming from a population undergoing mixed self and random mating. Biometrics 40: 157-164.

Davierwala AP, Chowdari KV, Kumar S, Reddy AP, et al. (2000). Use of three different marker systems to estimate genetic diversity of Indian elite rice varieties. Genetica 108: 269-284.

Diaz A, De la Rosa R, Martin A and Rallo P (2006). Development, characterization and inheritance of new microsatellites in olive (Olea europaea L.) and evaluation of their usefulness in cultivar identification and genetic relationship studies. Tree Genet. Genomes 2: 165-175.

Dinelli G, Bonetti A, Marotti I, Minelli M, et al. (2004). Characterization of Italian populations of Lolium spp. resistant and susceptible to diclofop by inter simple sequence repeat. Weed Sci. 52: 554-563.

Doyle J and Doyle J (1987). A rapid DNA isolation procedure for small quantities of fresh leaf tissue. Phytochem. Bull. 19: 11-15.

Excoffier L, Smouse PE and Quattro JM (1992). Analysis of molecular variance inferred from metric distances among DNA haplotypes: application to human mitochondrial DNA restriction data. Genetics 131: 479-491.

Garcia A and Lindner R (1998). Dactylis glomerata genetic resources: Allozyme frequencies and performance of two subspecies on and acid sandy loam with summer drought. Euphytica 102: 255-264.

Goodman SJ (1997). $\mathrm{R}_{\mathrm{st}}$ Calc: a collection of computer programs for calculating estimates of genetic differentiation from microsatellite data and determining their significance. Mol. Ecol. 6: 881-885.

Hogbin MP and Peakall R (1999). Evaluation of the contribution of genetic research to the management of the endangered plant Zieria prostrata. Conservat. Biol. 13: 514-522.

Huang Y, Zhang CQ and Li DZ (2009). Low genetic diversity and high genetic differentiation in the critically endangered Omphalogramma souliei (Primulaceae): implications for its conservation. J. Syst. Evol. 47: 103-109.

Kalinowski ST (2005). Do polymorphic loci require large sample sizes to estimate genetic distances? Heredity (Edinb.) 94: 33-36.

Kalinowski ST and Taper ML (2006). Maximum likelihood estimation of the frequency of null alleles at microsatellite loci. Cons. Gene. 7: 991-995.

Kölliker R, Stadelmann FJ, Reidy B and Nosberger J (1999). Genetic variability of forage grass cultivars: A comparison 
of Festuca pratensis Huds., Lolium perenne L., and Dactylis glomerata L. Euphytica 106: 261-270.

Litrico I, Bech N, Flajoulot S, Cadier D, et al. (2009). Cross-species amplification tests and diversity analysis using 56 PCR markers in Dactylis glomerata and Lolium perenne. Mol. Ecol. Resour. 9: 159-164.

Lumaret R (1997). Polyploidy and the critical size of natural population: the case of cocksfoot (Dactylis glomerata L.) a grass used as a fodder plant. Bocconca 7: 133-139.

Metin T, Khadka DK, Shrestha MK, Arumuganathan K, et al. (2004). Characterization of natural orchardgrass (Dactylis glomerata L.) populations of the Thrace Region of Turkey based on ploidy and DNA polymorphisms. Euphytica 135: 39-46.

Michalakis Y and Excoffier L (1996). A generic estimation of population subdivision using distances between alleles with special reference for microsatellite loci. Genetics 142: 1061-1064.

Nei M (1973). Analysis of gene diversity in subdivided populations. Proc. Natl. Acad. Sci. U. S. A. 70: 3321-3323.

Nei M (1978). Estimation of average heterozygosity and genetic distance from a small number of individuals. Genetics 89: 583-590.

Painter EL, Detling JK and Steingraeber DA (1993). Plant morphology and grazing history. Vegetatio 106: 37-62.

Papanastasis VP, Kyriakakis S and Kazakis G (2002). Plant diversity in relation to overgrazing and burning in mountain mediterranean ecosystems. J. Mediterr. Ecol. 3: 53-63.

Parissi ZM, Abraham EM, Karameri E and Kexagia E (2007). Comparable Study of the Nutritive Value in Greek populations of Dactylis glomerata L. Growing in Contrasting Environments in Association to Maturity Proceedings of EGF Conference: Permanent and Temporary Grassland, Plant, Environment and Economy. (Vliegher ADe and Carlier L, eds.). Grassland Science in Europe, Ghent, 371-374.

Peakall R and Smouse PE (2006). GENALEX 6: genetic analysis in Excel. Population genetic software for teaching and research. Mol. Ecol. Notes 6: 288-295.

Peng Y, Zhang X, Deng Y and Ma X (2008). Evaluation of genetic diversity in wild orchardgrass (Dactylis glomerata L.) based on AFLP markers. Hereditas 145: 174-181.

Peter-Schmid MKI, Boller B and Kölliker R (2008). Habitat and management affect genetic structure of Festuca pratensis but not Lolium multiflorum ecotype populations. Plant Breeding 127:510-517(518).

Raymond M and Rousset F (1995). Genepop (Version-1.2) - Population-genetics software for exact tests and ecumenicism. J. Hered. 86: 248-249.

Sahuquillo E and Lumaret R (1999). Chloroplast DNA variation in dactylis glomerata L. taxa endemic to the macaronesian islands. Mol. Ecol. 8: 1797-1803.

Steel RGD and Torrie JH (1980). Principles and Procedures of Statistics. Mcraw-Hill, New York.

Volis S, Mendlinger S, Olsvig-Whittaker L and Safriel UN (1998). Phenotypic variation and stress resistance in core and peripheral populations of Hordeum spontaneum. Biodiversity and Conservation 7: 799-813.

Wang Z, Liao L, Yuan X and Gua H (2013). Genetic diversity analysis of Cynodon dactylon (bermudagrass) accessions and cultivars from different countries based on ISSR and SSR markers. Biochem. Syst. Ecol. 46: 108-115.

Wolf AT, Howe RW and Hamrick JL (2000). Genetic diversity and population structure of the serpentine endemic Calystegia collina (Convolvulaceae) in northern California. Am. J. Bot. 87: 1138-1146.

Xie WG, Zhang XQ, Ma X and Cai HW (2010). Diversity comparison and phylogenetic relationships of cocksfoot (Dactylis glomerata L.) germplasm as revealed by SSR markers. Can. J. Plant Sci. 90: 13-21.

Xie WG, Lu XF, Zhang XQ, Huang LK, et al. (2012). Genetic variation and comparison of orchardgrass (Dactylis glomerata L.) cultivars and wild accessions as revealed by SSR markers. Genet. Mol. Res. 11: 425-433.

Yeh F, Boyle T, Rongcai Y and Ye Z (1999). Popgene Version 1.31. Microsoft Window-Based Freeware for Population Genetic Analysis. 